\title{
The Effect of Job Characteristic, Person-Job Fit, Organizational Commitment on Employee Performance (Study of East Java BPJS Employees)
}

\author{
Gunawan Eko Nurtjahjono ${ }^{\mathrm{a}}$, Umar Nimran ${ }^{\mathrm{b}}$, Muh. Al Musadieq ${ }^{\mathrm{b}}$ and Hamidah Nayati Utami ${ }^{\mathrm{b}} *$ \\ ${ }^{a}$ Business Administration Doctoral Program, Faculty of Administrative Sciences, University of Brawijaya, Malang Indonesia \\ ${ }^{b}$ Faculty of Administration Science, University of Brawijaya
}

\section{ARTICLE INFORMATION}

Article history:

Data submission : 13 October 2019

$1^{\text {st }}$ revision: 1 December 2019

Accepted: 1 January 2020

Available online: 2 February 2020

Keywords: job characteristic, person-job fit, organizational commitment, and employee performance

\section{ABSTRACT}

\begin{abstract}
Employee performance is the key to the success of an organization. The top priority of organizational leaders is how to create employees as prime human resources, have good behavior in the workplace and perform well based on needs in the workplace and have an understanding of the values that exist and are applied in the organization. The purpose of this study is to analyze and determine the effect of job characteristics, person-job fit, organizational commitment to employee performance. The population in this study were employees in East Java Province BPJS Employment with a total of 238 as a research sample. The research method uses survey research by distributing questionnaires to respondents. While the analysis of research data using Warp-PLS. The results showed that (1). The effect of job characteristics on person-job fit is positive and significant, (2). The effect of job characteristics on organizational commitment is positive and significant (3). The effect of job characteristics on employee performance is positive and significant (4). The influence of person-job fit on employee performance is positive and significant (5). The effect of organizational commitment on employee performance is positive and significant
\end{abstract}

2020 FIA UB. All rights reserved.

\section{Introduction}

Employees are the principal capital that must be considered to achieve optimal organizational performance. Organizational success can be measured by the effectiveness or failure of employee performance. According to $\mathrm{Li}$ (2016), Johari (2015), excellent employee performance can determine organizational success in achieving the vision and mission goals of the organization. Therefore, organizational leaders need to study the factors of job characteristics, person-job fit, and organizational commitment. According to, Klaus (2014), Batchelor (2014) employees need by organizations such as the physical work environment, opportunities for advancement are need by employees and vice versa, organizations need employee contributions in the form of commitment, their expertise, and abilities.

Research conducted by Jawad (2013), Hussain (2017), Alla (2017) shows that job characteristic, person-job fit, and organizational commitment has positive and significant effects on employee performance. In contrast, Leng (2016) study showed that the variable of job characteristics, person-job fit, and organizational commitment did not have a significant effect on employee performance.

Research by Berg (2003), June (2011) shows that there is a correlation between job characteristics and employee desire to realize employee performance. The same result was shown by $\mathrm{Gu} \mathrm{Ne}$ (2016), whereas different research results are shown by Irefin (2014), who examines the relationship between organizational commitment to employee performance. Jie (2013) research shows that affective commitment, normative commitment, and continuous commitment do not significantly influence employee performance.

The transformation of the state-owned enterprise, PT. Jamsostek, into a Manpower Social Security Organizing Agency engaged in the field of social insurance in the current era, has faced various global changes and competitive competition that makes organizations must immediately develop management in more organized management without losing its function as BUMN. With 
an increasingly advanced implementation system, the BPJS Employment program not only provides benefits to workers and employers but also makes an essential contribution to improving the nation's economic growth and the welfare of the Indonesian people.

\section{Theory}

Job Characteristics proposed by Luthans (2006) is an approach in designing work that shows how to work described in five core dimensions of work. The job characteristics variable uses five indicators, namely: variation of skills, task identity, task significance, autonomy, and job feedback.

Person-Job Fit according to Holland (2000) is compatibility between individual ability with the demands of the job or the desires of a person with work attributes. The benefits for the organization if there is a match between the personal characteristics of individuals with the type of work that can improve individual performance. The person-job fit variable is need-supply fit and demand-ability fit.

Organizational commitment according to Dessler (2012) is a feeling of identification, involvement, loyalty expressed by employees of the organization. Davis (2000) states that organizational commitment is a strong desire to remain as a member of the organization, a desire to work following organizational desires and acceptance of organizational values and goals. The indicators of organizational commitment are an affective commitment, normative commitment, and continuous commitment.

Employee performance, according to Robbins (2007) is the result of the quality and quantity of work achieved by an employee in carrying out their functions by following the responsibilities assigned to the employee. The indicators of employee performance are quality, quantity, timeliness, attendance, and cooperation.

\section{Research Method}

This research uses explanatory research type. Explanatory research is research that explains the causal relationship between variables and testing hypotheses, using survey research and questionnaires as data collection instruments. The population of this research is the workers of National Health Insurance or BPJS Employee in East Java Province with a sample of 238 respondents.

The type of data used is primary data and secondary data. Sugiyono (2007) states primary data is data obtained from respondents directly through a questionnaire using survey methods. Primary data sources are data sources that directly provide data to researchers. The primary data source in this study obtained from respondent data, namely BPJS Employment employees. The secondary data is research data obtained indirectly through intermediary media such as historical reports arranged in archives or documentary data. Secondary data in this study are in the form of organizational structure, several companies, and documentation in BPJS Employment of East Java Province.
Data analysis methods used are descriptive statistical analysis and inferential statistical analysis. Inferential statistical analysis in this study used the Warp-PLS analysis, according to Solimun (2016) The Warp-PLS analysis is used based on the conceptual model of this research as a multi-influence and tiered influence. Besides, the variables analyzed in this study are latent with the indicator model being reflective and formative. Results.

Table 1. Loading Factor Indicator for Job Characteristic Variable, Person-Job Fit, Organizational Commitment, Employees Performance

\begin{tabular}{|c|c|c|c|c|}
\hline Variables & indicators & items & $\begin{array}{l}\text { loading } \\
\text { factors }\end{array}$ & $p$ value \\
\hline \multirow[t]{10}{*}{ Job Characteristic } & Variety & $\mathrm{X} 1.1 .1$ & 0.126 & 0.024 \\
\hline & Skills & $\mathrm{X} 1.1 .2$ & 0.169 & 0.004 \\
\hline & Task Identity & $\mathrm{X} 1.2 .1$ & 0.183 & 0.002 \\
\hline & & $\mathrm{X} 1.2 .2$ & 0.180 & 0.002 \\
\hline & Task & $\mathrm{X} 1.3 .1$ & 0.186 & 0.002 \\
\hline & Significance & $\mathrm{X} 1.3 .2$ & 0.154 & 0.008 \\
\hline & Autonomy & $\mathrm{X} 1.4 .1$ & 0.108 & 0.045 \\
\hline & & $\mathrm{X} 1.4 .2$ & 0.167 & 0.004 \\
\hline & Feedback & $\mathrm{X} 1.5 .1$ & 0.167 & 0.004 \\
\hline & & $\mathrm{X} 1.5 .2$ & 0.147 & 0.010 \\
\hline \multirow[t]{4}{*}{ Person-Job Fit } & Need-Supply & Y1.1.1 & 0.286 & $<0.001$ \\
\hline & Fit & $\mathrm{Y} 1.1 .2$ & 0.340 & $<0.001$ \\
\hline & Demand- & $\mathrm{Y} 1.2 .1$ & 0.380 & $<0.001$ \\
\hline & Ability Fit & $\mathrm{Y} 1.2 .2$ & 0.350 & $<0.001$ \\
\hline Organizational & Affective & Y2.1.1 & 0.214 & $<0.001$ \\
\hline \multirow{5}{*}{ Commitment } & Commitment & $\mathrm{Y} 2.1 .2$ & 0.211 & $<0.001$ \\
\hline & Normative & Y2.2.1 & 0.253 & $<0.001$ \\
\hline & Commitment & $\mathrm{Y} 2.2 .2$ & 0.157 & 0.007 \\
\hline & Continuous & $\mathrm{Y} 2.3 .1$ & 0.250 & $<0.001$ \\
\hline & Commitment & Y2.3.2 & 0.242 & $<0.001$ \\
\hline Employee & Quality & Y3.1.1 & 0.137 & 0.016 \\
\hline \multirow[t]{9}{*}{ Performance } & & Y3.1.2 & 0.135 & 0.017 \\
\hline & Quantity & Y3.2.1 & 0.146 & 0.011 \\
\hline & & Y3.2.2 & 0.118 & 0.032 \\
\hline & Punctuality & Y3.3.1 & 0.137 & 0.016 \\
\hline & & Y3.3.2 & 0.144 & 0.012 \\
\hline & Presence & Y3.4.1 & 0.124 & 0.026 \\
\hline & & Y3.4.2 & 0.138 & 0.015 \\
\hline & Cooperation & Y3.5.1 & 0.142 & 0.013 \\
\hline & & Y3.5.2 & 0.136 & 0.017 \\
\hline
\end{tabular}

Hypothesis testing is done using Warp-PLS analysis. The results of hypothesis testing as described in the figure 1 .

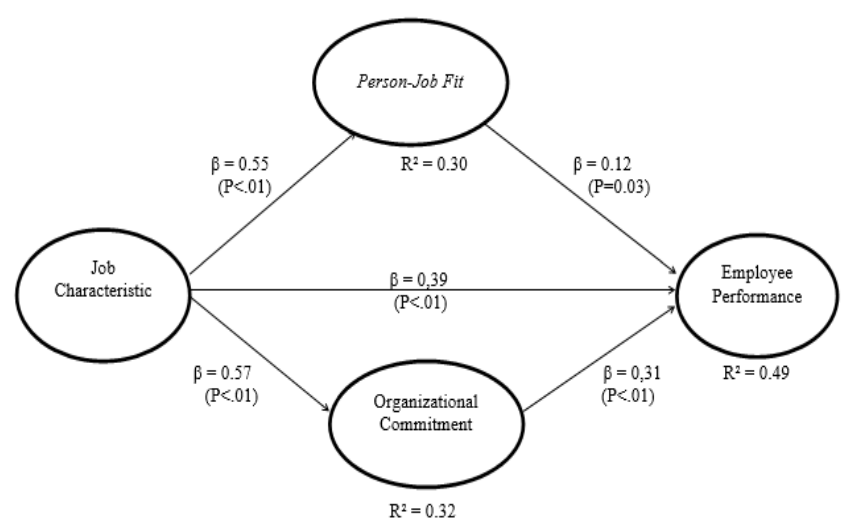

Figure 1. Hypothesis testing results 
Table 2. SEM results

\begin{tabular}{|c|c|c|c|}
\hline Exogenous variables & $\begin{array}{l}\text { endogenous } \\
\text { variables }\end{array}$ & $\begin{array}{c}\text { path } \\
\text { coefficient }\end{array}$ & $p$-value \\
\hline Job Characteristic & Person-Job Fit & $0.546^{* * *}$ & $<0.001$ \\
\hline Job Characteristic & $\begin{array}{l}\text { Organizational } \\
\text { Commitment }\end{array}$ & $0.568 * * *$ & $<0.001$ \\
\hline Job Characteristic & $\begin{array}{l}\text { Employee } \\
\text { Performance }\end{array}$ & $0.392 * * *$ & $<0.001$ \\
\hline Person-Job Fit & $\begin{array}{l}\text { Employee } \\
\text { Performance }\end{array}$ & $0.120 * *$ & 0.030 \\
\hline $\begin{array}{l}\text { Organizational } \\
\text { Commitment }\end{array}$ & $\begin{array}{l}\text { Employee } \\
\text { Performance }\end{array}$ & $0.307 * * *$ & $<0.001$ \\
\hline
\end{tabular}

\section{Discussion and Conclusion}

The results of the analysis of the effect of job characteristics on person-job fit, the value of the path coefficient is 0.546 ( $p$-value <0.001). This shows better job characteristics, the better the person-job fit in the organization.

The results of the analysis of the influence of job characteristics on organizational commitment, the path coefficient value are 0.568 ( $p$-value $<0.001)$. The result shows better job characteristics, the better the organizational commitment of employees in the organization. The results of the analysis of the effect of job characteristics on person-job fit, the value of the path coefficient is 0.392 ( $p$-value <0.001). This result shows the better job characteristics, the better the person-job fit.

The results of the analysis of the influence of personjob fit on Employee Performance, the path coefficient value is 0.120 ( $p$-value $<0.001)$. This result shows that the better the person-job fit, the better the performance of employees in the organization.

The results of the analysis of the effect of organizational commitment on employee performance, the path coefficient value are 0.307 ( $p$-value $<0.001)$. The result is significant. The result shows a better organizational commitment, the better the performance of employees in the organization. The results of this study show that the effect of job characteristics on person-job fit is positive and significant. The effect of job characteristics on organizational commitment is positive and signifikan. The effect of job characteristics on employee performance is positive and significant. The influence of person-job fit on employee performance is positive and significant. The effect of organizational commitment on employee performance is positive and significant.

\section{References}

Alla,A.(2017), Impact of Person-Job Fit, PersonOrganization Fit, Information Sharing and Empowerment on Organizational Commitment of Morrocan Bank Managers, International Journal of Emerging Research in Management \& Technology, 6(2)16-22.

Berg,P.(2003), Complex Relationships Among Personality Traits, Job Characteristics and Work
Behaviors, International Journal of Selection and Assessment, 11(4)326-339.

Batchelor,J.(2014), The Job Characteristics Model:An Extension to Entrepreneurial Motivation,Small Business Institute Journal,10(1)1-10.

Davis,K,(2000), Human Behavior at work, Eight edition,Mc.Graw-Hill, Book Cmpany,New York.

Dessler,G,(2012), Human Resource Management, Prentice Hall Pearson Education Inc.

$\mathrm{Gu} \mathrm{Ne},(2016)$, Towards high performance organization: The impacts of job characteristics and job crafting, International Journal Service and Technology, 9(2)85-100

Hooland,(2000), Making Vocational Choices : A Theory of Vocational Personalities and Work Environtment, 2nd Edition, Prentice Hall.

Hussain,H,(2017), Person Job-Fit and Job Performance Among Non-Governmental Organization Workers:A Conceptual Framework, International Journal of Accounting, Finance and Business, 2(5)108-122

Irefin,F.(2014),Effect of Employee Commitment on Organizational Performance in Coca-Cola Nigeria Limited Maiduguri Borno State, Journal of Humanities and Social Science,19(3)33-41

Jawad,(2013), Study on work place behavior:role of person-organization fit, person-job fit \& empowerment, evidence from pakistan, Journal of Business and Management Sciences, 1(4)47-54

Jie,F(2013), Analysis of the Effect of Attitude Toward Works, Organizational Commitment and Job Satisfaction on Employee Job Performance, European Journal of Business and Social Sciences, 1(10)15-24

Johari,J.(2015), Elevating Job Performance Through Job Characteristics and Work Involvement, International Academic Research Journal of Social Science, 1(2)69-82

June,S (2011), The Relationship Between Person-Job Fit and Job Performance : A Study Among the Employee of the Services Sector SMEs in Malysia, International Journal of Business, Humanities and Technology,1(2)95-105

Klaus,T.(2014), System developer's nature of work characteristics and their relationship with organizational commitment and job satisfaction, Journal of Information Technology Management,25(1)1-19

Leng,G.(2016),Person-JobFit,Personality,Organizational Commitment and Intention to Stay Among Employees in Marketing Department, Journal Psychology Malysia,30(1)80-89

Li,H.(2016), Exploring the effects of active job characteristics on employee work alienation and work performance employment form as moderator, Journal of Residuals Science \& Technology, 13(7)1-7

Luthans, F. (2006), Organizational behavior, New York: Mc.Graw-Hills International Edition.

Robbins,S(2007), Organizational Behavior (12thEd) New York : Prentice Hall.

Solimun,(2016), Penguatan conformatory research pemodelan persamaan struktural Warp-PLS, Diktat Diklat, Aplikasi Statistika Universitas Brawijaya Malang

Sugiyono, (2007), Metode penelitian administrasi, Edisi 9, Bandung : Penerbit Alfabeta. 